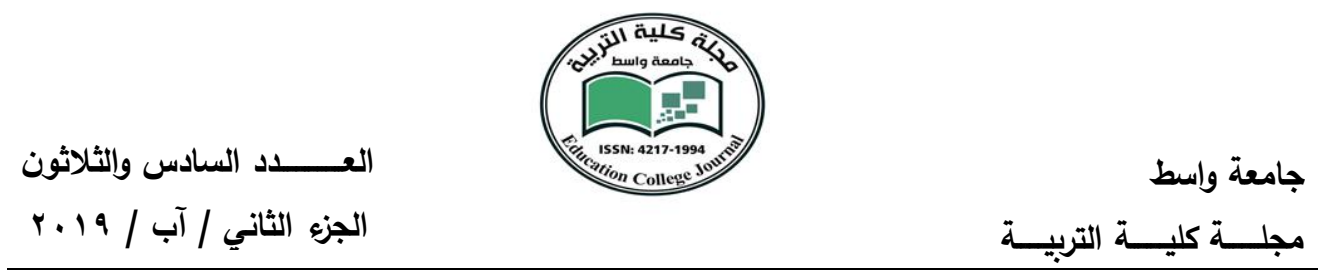

\title{
النفاق وتأصيله للفساد في ضوء القرآن والسنة
}

أ.م.د. ل أبنى حسن عذيب

الباحث: حسن عبيد كريم

جامعة واسط / كلية التربية للعلوم الإنسانية

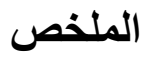

يهدف الى بيان مدى العلاقة الوثيقة بين النفاق والفساد في الأرض ، وقد سار الباحث في

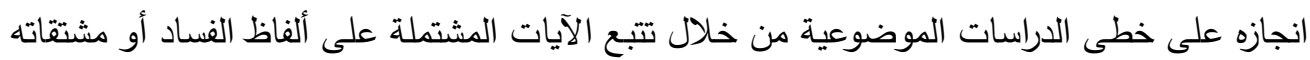
ـ ممن يُقصد بها النفاق أو المنافقين . والتدبر فيها والتثريع عليها .

وقد اشتمل البحث على ثلاثة مطالب تكثف لنا عن مدى هذه العلاقة بينهما ـ أي النفاق

والفساد في الأرض ـ كان الأول منها مختصّاً بكثف مدلول النفاق اللغوي والاصطلاحي ، وكيفية

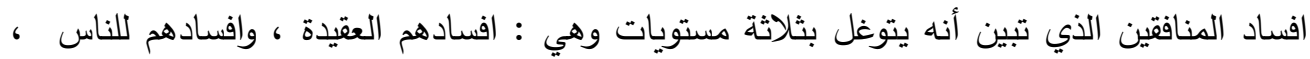
وثالث يكون نتيجة طبيعية لهما وهو افسادهم النظام العام من خلال ما يترتب على المستويات السابقة

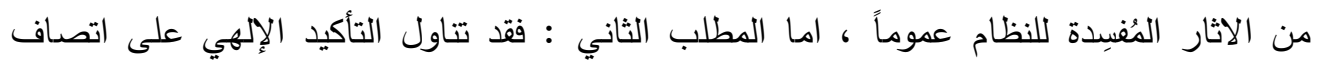
المنافقين بالفساد الذي تبين فيه أن القرآن الكريم قد اكد افسادهم في اكثر من موضع ، واما المطلب

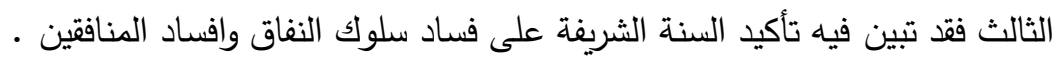

فالنفاق إذن سلوك فاسد بذاته مُفِدِد بما يترتب عليه من الآثار ، التي تكون مؤصلة لحلول

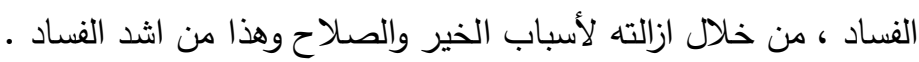




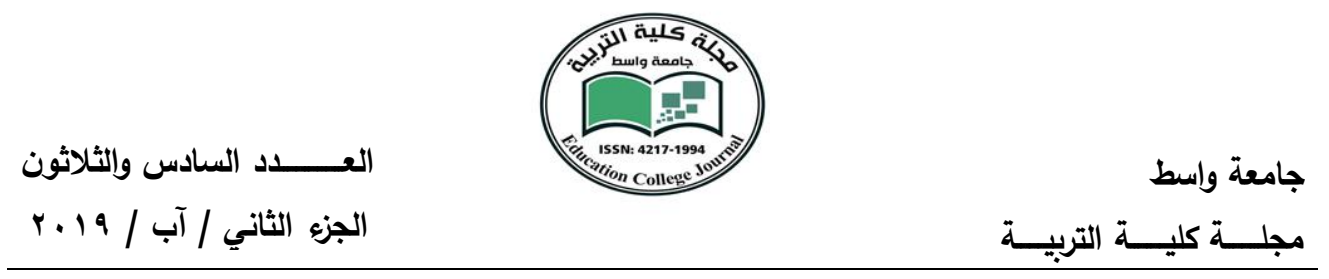

\section{$\underline{\text { Abstract }}$}

It was an attempt aimed at showing the extent of the close relationship between hypocrisy and corruption in the land, and the researcher has followed in the footsteps of the objective studies through the tracking of verses containing the words of corruption or oppressors who are intended hypocrisy or hypocrite

The research included three axes that reveal to us the extent of this relationship between them, ie, hypocrisy and corruption in the land, the first of which was specialized in revealing the meaning of hypocrisy and language, and how to corrupt the hypocrites, which turned out to be penetrating three levels: The second axis dealt with the divine emphasis on the hypocrisy of the hypocrites, which showed that the Holy Qur'an had confirmed their corruption in more than one place. In which the honorable year confirms the corruption of the behavior of hypocrisy and corrupt the hypocrites.

The hypocrisy is a corrupt behavior in itself, corrupting its consequences, which are the root causes of corruption solutions, through the removal of the causes of good and righteousness and this is the most corrupt. 
العــــــدد السادس والثثلاثون

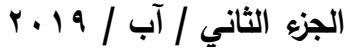

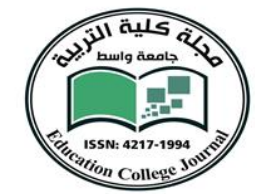

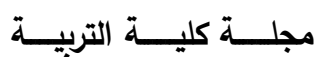

\section{المقدمة}

الحمد لله رب العالمين والصلاة والسلام على أفضد خلقه أجمعين ( محمدٍ ) الذي اجتباه ليخلّص خلقه من ظلمات الجهل إلى نور الإسلام وعلى آله الاطهار المصطفين أئمة الهـى وسادة العباد ، وصحبه المنتجبين الى يوم الدين وبعد...

يصنف الناس · من المنظور الاعتقادي أو الإيماني . الى صنفين متناقضين بالمعتقدات منهم المؤمن ومنهم الكافر وكلاهما قد لا يتحرج بإظهار ما يعتقد ويؤمن به ، واجتماعهما . في شخص واحد ـ اقرب الى المحال للتناقض المذكور ، وبذلك فإن الكفر يشكل خطراً على الاسلام ومعتنقيه خاصة وأن هناك من هو ضعيف الإيمان ولم يسرِ به إلى قلبه ، ولكن هذا الخطر سرعان ما يكون صغيراً إذا ما علمنا بوجود صنف آخر يجمع ذينك النقيضين ، ولما كان اجتماعهما محال كان ذلك مؤكداً لاتصاف هذه الفئة بالازدواجية والتتاقض ، وهذا الصنف من الناس هم المنافقين الذين لا تلاؤم بين ظاهرهم وباطنهم ، فهم أشدّ خطراً على الاسلام ، كونهم يتلونون بألوان شتى حسب ما تقتضيه المصلحة ، فهم مع كفرهم زادوا عليه تناقضا بين الظاهر والباطن وادعاء الإصلاح فهم كفار وزيادة ، ويظهرون بلباس الاسلام ، وبدون ادنى شك ان هذه الازدواجية هي مرض في قلوبهم ؛ لأن الإنسان السوي السليم واضح الموقف إما مؤمن وإما كافر .

ويزداد خطرهم بتوغلهم ودخولهم مع المسلمين بلباس الدين مما يطمئن المسلمون لهم ، وما كان دخولهم إلا لغاية ضرب الاسلام والمسلمين من الداخل وافشاء أسرارهم للكفار ، والعمل على إضعافه من خلال معرفة وتشخيص مكامن القوة والضعف لدى المسلمين ، لذلك فمن الصعب جداً تمييزهم ومعرفتهم لتظاهرهم بالإسلام وادعاءهم اعتناقه ، ومثل هذه الاوصاف هي حتماً من مؤصلات ومسببات الفساد في الأرض سواء لفساد الفعل ذاته أو بما يترتب عليه من الآثار المُفسِدة ، وقد عبّر القرآن الكريم عن المنافقين في بعض المواضع بأنهم من المفسدين في الأرض ، وبناء على ذلك ، ولكثرة انتشار النفاق وأهله فقد أراد الباحث في هذا الموضع إبراز الجانب المُفِِد للنفاق والمنافقين بالاعتماد على ما يطرحه القرآن وتؤيده السنة متتبع في ذلك ألفاظ الفساد ومشتقاته ممن يراد بها 
العـــــــد السادس والثثلاثون

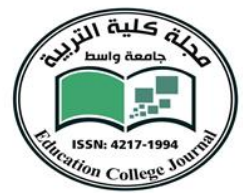

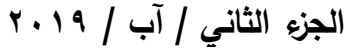

جامعة واسط

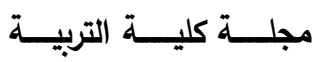

النفاق وأهله ، وأما السنّة فقد وقع الاختيار على كتاب الكافي ـ انموذجاً . للشيخ الكليني ؛ لِقدَمه وثقة مؤلفه الذي يلقب بـ " ثقة الإسلام " وبالمجمل فإن البحث كان على النحو التالي :

المطلب الأول : مفهوم النفاق وكيفية افساد المنافقين :

$$
\text { ا I افسادهم للعقيدة }
$$

r. (فسادهم الناس والنظام العام

المطلب الثاني : التأكيد الإلهي على اتصاف المنافقين بالفساد

المطلب الثالث : تأكيد السنة لهذا الفساد

ثم تعقبها الخاتمة التي ذكر بها الباحث أهم ما توصل إليه من نتائج •

هذا واسأل الله ان يتقبله بأحسن قبول فإن كان يشوبه خطأ فيكفي شرف المحاولة خدمة

لكتاب الله وطلبة علمه ولا ادعوه إلا أن يغفر لي ويعفو عني ، وآخر دعوانا أن الحمد لله رب العالمين

والصلاة والسلام على محمد وآله وصحبه المنتجبين . 
العـــــــد السادس والثلاثون

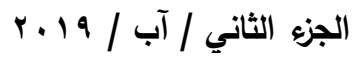

جامعة واسط

مجلـــة كليـــة التربيــة

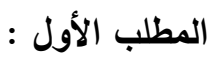

مفهوم النفاق وكيفية إفساد المنافقين

النفاق في اللغة : (( مشتق من النفق وهو السرب في الأرض )(') ) وهو ما يعطي معنى

التستر والاخفاء الذي ينطبق على المنافق بكونه يدخل الاسلام من وجه ويخرج عنه بآخر (r) ،

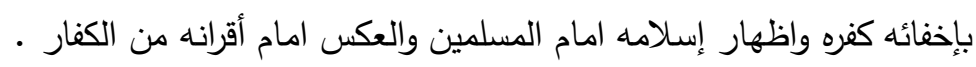

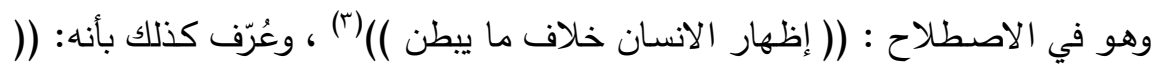

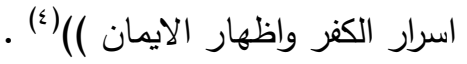

لاللك تكفل القرآن بمهمة تمييزهم ففضح امرهم وبيّن بدقة في عديد الآيات صفاتهم ، مؤكدا

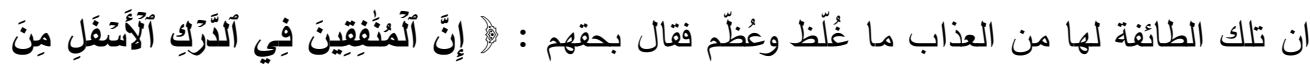

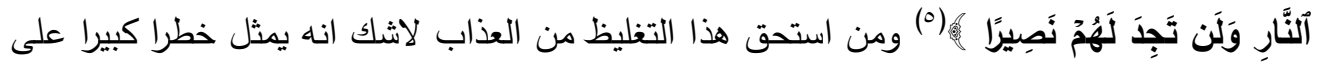

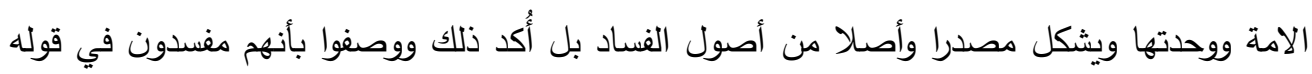

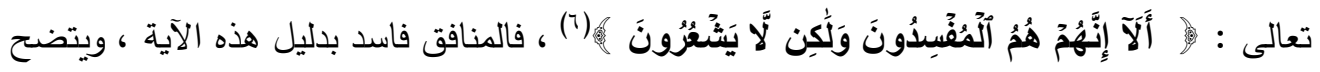
فسادهم بتعدد وإختلاف تصرفاتهم السيئة وارتكابهم المعاصي وقيامهم بأفعال من شأنها الافساد في الأرض ، وقد أكد تعالى في كتابه قبح صنيعهم بصريح عبارة الفساد في اكثر من موضع منها قوله

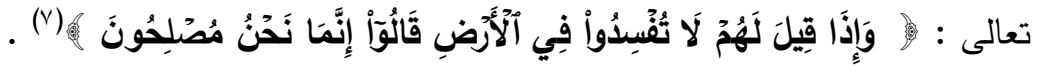

لابد من الإثارة إلى أن الآية واردة في سياق متواصل عن المنافقين يبين اوصافهم ويوضح علاماتهم كي يتم تمييزهم ، ومن هذه العلامات هي افسادهم في الأرض ، ومن المعلوم ان افساد اي طائفة لابد ان يتخذ منحئ معين إذ أن وجوه الفساد تتعدد وتختلف بإختلاف الهدف ، ويبدو ان النفاق شمل اغلب وجوه الفساد ، ومن خلال آراء اهل التفسير في توضيح افساد المنافقين من خلال هذه الآية يتبين ان افسادهم تارة يكون على مستوى العقيدة واخر على مستوى الناس وثالث على النظام

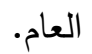


العــــــدد السادس والثثلاثون

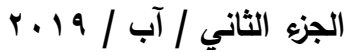

جامعة واسط

مجلــــة كليـــــة التربيــــة

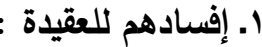

فأما العقيدة فإفسادهم لها متعدد الاوجه فقيل : بالكفر (^) والثابت ان المنافق كافر ، والكفر من الفساد في الأرض ؛ لما فيه من كفران النعم وإنعدام وجود الرادع الذي يكون دافعا للعمل وفقا للهوى ؛ ولأن من لا يعتقد بوجود إله لا يرجو ثوابا ولا عقابا فيكون ذلك مدعاة للتهارج واشاعة (الفساد) (9)

وقيل : بإرتكابهم معصية الله والعمل بها(·) ، وارتكابهم المعاصي فساد في الأرض ؛ لان اصلاح الأرض لا يكون إلا بالطاعة وامتثال أمر الله('") ، فالشرائع هي قوانين وسنن موضوعة بين الخلق والتمسك بها يعني العيش بسلام وامان كونها داعيه لإنْ يلتزم كل فرد بشأنه فتسكن الفتن وتحقن الدماء وفي ذلك صلاح الأرض لصلاح اهلها(rا) ، وقيل ايضا : بالصدّ عن اتباع دين الله تعالى وتفريق الناس عن الايمان بمحمد والقرآن(r')، وفي هذا من الفساد ما لا يخفى فالنهي والاعراض عن دين الله دافع لئن يقود الناس لعبادة من ليس أهلا للعبادة كالأصنام والاوثان وحتى عبادة البشر(ءء)، ومن افساداتهم على مستوى العقيدة أيضا عملهم بنواهي الله واجتابهم أوامره وتضييعهم ما امرهم بحفظه(10) بقصدهم تغيير الملة وتحريف الكتاب والسنة(ب (1) .

وقد اكد ذلك الطبري ( ت · اسه ) وأوجزه بقوله : (( إن صفة أهل النفاق مفسدون في الأرض بمعصيتهم فيها ربهم ، وركوبهم ما نهاهم عن ركوبه وتضييعهم فرائضه ، وشكهم في دين الله

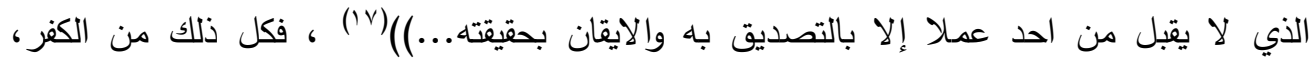
والمعاصي، والاعراض عن الدين ، وغيرها من الافعال القبيحة التي تصدر من اهل النفاق هي افساد منهم في الأرض بإخلالهم للعقيدة لان ما ذكر هي أمور تتعلق بالعقيدة وهي مخلّة بها وبالتالي فإن ارتكابها يمثل اخلالا وافسادا للعقيدة وبالتالي إفسادا في الأرض. 
العــــــدد السادس والثثلاثون

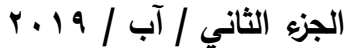

جامعة واسط

مجلــــة كليـــــة التربيــــة

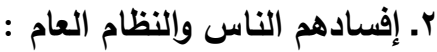

ويتعدى افساد المنافقين افساد العقيدة الى إفساد الناس والنظام العام من خلال الافعال التي

ينتج عنها ذلك ، فيتمثل افسادهم للناس ببث هذه الصفات الذميمة والدعوة اليها واتخاذهم قدوة سيئة من قبل ابناءهم وعيالهم(^) ، وبإشاعاتها - هذه الصفات - بين الناس وبذرها بأبنائهم إفساد لهم وضمان لحاضر ومستقبل منحرف لهم وتبني للفساد وتأصيل له ، وهذا إفساد عظيم.

ومن أثد الأمور التي يقوم بها المنافقون خطرا على المسلمين توغلهم وتداخلهم معهم بحجة الإسلام إلا إنهم لا يألون للمسلمين ويدعون لترك نصرة الرسول واتباعه(9')، ومداراتهم لأهل الكفر من خلال ايهامهم بضعف الرسول وضعف انصاره وفي ذلك تجرأة لهم على اظهار العداوة لهم وشن الحرب وطمعهم في الغلبة عليهم (·r)، وفي ذلك فساد عظيم ، بالإضافة الى افشاءهم لأسرار المسلمين واطلاع الكفار عليها مما يعني تسليطهم عليهم ومساعدتهم على ضرب المؤمنين('ا) وإلقاءهم الشبه في قلوب المستضعفين وجحد الاسلام ليشوشوا عليهم دينهم(r) ، وفي هذه الافعال الرذيلة ما يُفسد النظام بشكل عام ، ويبلغ افسـادهم ذروته بهيج الفتن وشن الحروب وفي هذا إفساد للأرض ومـا عليها من الناس والدواب والحرث والزروع والثمار وغير ذلك من المنافع الدينية والدنيوية التي ينتفع بها في الحياة(rr) وتمثل القوام الاساسي لبقاء الانسان واستقامة النظام ، والاخلال بذلك واتلافه يكون ملزما لإخلال وفساد النظام بعمومه ، ويكون ذلك بإلقاء النميمة والعداوة وتأليب الفتن على

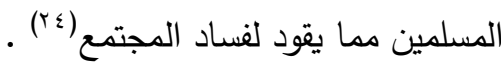

وهذه الرذائل أفعال فاسدة مُفسِدة للنظام الاجتماعي مخلّة بإستقامته ومُعكِرة لصفوّ الحياة فيه ، ويمكن تحديد وجه الفساد بشكل أدق من كل ما سبق من خلال معرفة ان هذه الافعال هي كبائر عظيمة ومعاصٍٍ كبيرة والاصرار عليها يزيدها تغليظا بكونها تؤول لإنعدام ونقص حاد بالخيرات والبركات كونها ذات علاقة عكسية مع الذنوب والمعاصي ، فتكثر الخيرات بقلة المعاصي وانعدامها ، وتتعدم بكثرتها ، لأنها سبب في منع الغيث الذي يعتبر عاملا رئيسيا في الحياة ، وهذا من اشد فساد 
العـــــــد السادس والثلاثون

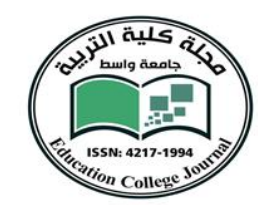

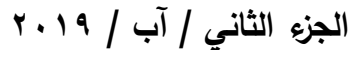

جامعة واسط

مجلـــة كليــــة التربيــــة

الأرض وخرابها(ro)، فالمنافقون يتعدى افسادهم عامة وجوه الفساد ليشمل جميعها ، ولهذا يعد من

اخطر المفاسد في الأرض •

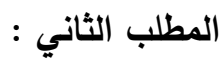

التأكيد الإلهي على اتصاف المنافقين بالفساد :

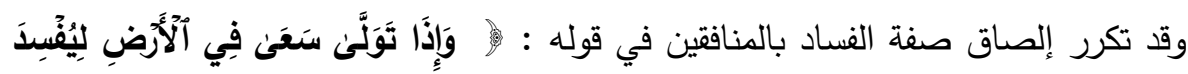

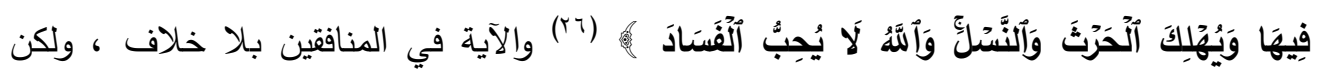
الخلاف وقع في المراد بـ " تولى " فأختلف المفسرون فيه بين الانصراف والادبار وبين الولاية والرئاسة وتسنّم زمام الحكم ، وكيف كان المراد فصفة الفساد ملازمة له وثابتة ، ويلاحظ ان الفساد الذي يصدر من المنافق في هذا الموضع متعلق بالجوانب الاجتماعية للحياة وما تتقوّم به بدليل تخصيص الفساد بإهلاك الحرث والنسل ، وهما من اهم الدعامات لقوام المجتمع.

فإذا كان المراد بـ " تولى " معنى الانصراف فإن فساده يكون عند ادباره وانصرافه عمّن

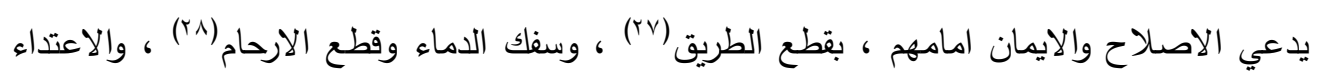
على الناس بإهلاك الحرث الذي يتمثل بالزروع والثمار ، والنسل الذي يعد امتداد للحياة بالأنسال(وج) ، واتلاف الاموال بتخريها وتحريقها ونهبها(·r)، وإثارة الثبه وادخالها في قلوب المسلمين واستخدامها في تقوية شوكة الكفر والكافرين ('r) ، وهذه من أبشع صور الفساد وأحقرها للآثار المترتبة عليها.

أما إذا كان المراد بـ " تولى " معنى الولاية والرئاسة فإن المراد ان المنافق اذا صار والياً لا يحكم الا بالظلم الذي يحكم به ولاة السوء والشر ، حتى يمنع الله بهذا الظلم القطر وبالتالي اهلاك الحرث والنسل (rrr)، وانطلق في المجالات التي تُقسِد الواقع الاجتماعي من إثارة النزاعات والخصومات ، واستعماله مختلف الوسائل التي من شأنها تدمير كل ما في الحياة من الثروات والبشر ، وهو المعبر عنه بالحرث والنسل(rr) ( 
العـــــــد السادس والثثلاثون

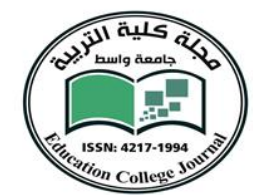

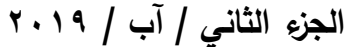

جامعة واسط مجلـــة كليــــة التربيــــة

فكلا المعنيين يلازمهما افساد المنافق ، ويبدو أن الاقرب هو التولي والإدبار لأن المنافق لا

يُظهِر نفاقه وعصيانه الا حينما ينصرف ويذهب عمّن يدعي امامهم الاسلام ، واستبعاد أن يُراد به الولاية والسلطان ؛ لان من تولى هكذا منصب لا يمنعه حينئذ من إظهار كفره مانع ولا يضطره لإن يكون منافقاً ضرر ؛ كونه يتمركز بمركز يتيح له ما يحب أن يفعل .

ومن ثم تقييد فساد المنافق بإهلاكه الحرث والنسل ، تقييد يراد به معنى العموم والاطلاق فهو يشمل :(( إتلاف كل الموجودات الحية أعمّ من الاحياء النباتية والحيوانية والإنسانية )(ع) فهو تعبير موجز · يعم كل مفردات الحرث والنسل . يشمل الافساد والتخريب بالنسبة للأموال والنفوس بالمجتمع البشري(ro) ، وهذا أعظم ما يحتاج اليه الانسان لعمارة الأرض ، وإفساده يمثل أعظم

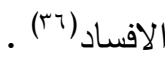

فإهلاكك الحرث والنسل كناية عن :(( إختلال ما به قوام أحوال الناس ()(rv) ، والتقييد بهما يراد به هذا الجانب الاجتماعي الذي يكون عاملا مساعدا وقواما اساسيا للحياة البشرية وامتدادها. ومـا يؤكد على تعظيم سماجـة هذه الأفعال هو ما ذكره تعالى في ذيل الآية بقوله : إَآلَّهُ

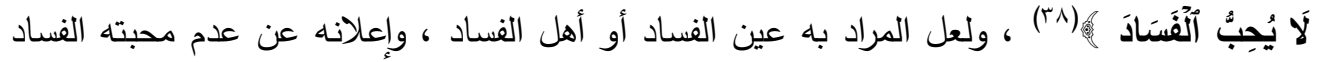
هو اعلان منه لكراهته وبغضه للمفسدين(ج) ، وهو دليل على نفي الرضا عنه وعن فاعله ، وعدم رضاه ـ تعالى · سبيل لعقاب فاعله حتما(•؛) ، لما فيه من خراب الامور الدينية ونظام الأحوال الدنيوية ومخالفته لما تقضيه حكمة الاصلاح وتعطيله لخلق الله وهذا غير محبوب عنده تعالى ( (؛) ، فيستحق بذلك عذابه للفساد الصادر منه. 
العـــــــد السادس والثلاثون

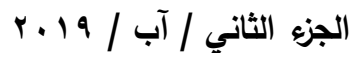

جامعة واسط

مجلـــة كليـــــة التربيــــة

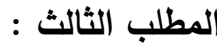

وعرضت السنة من هذا المنطلق القرآني .كون السنة شارحة ومفسرة للقرآن وموضحة لأمور

اخرى لم يتطرق لها ـ لمفسدة النفاق وبيانه متمثلا بأصوله وما يؤول إليه من الدفاسد ، ويظهره بمظهر

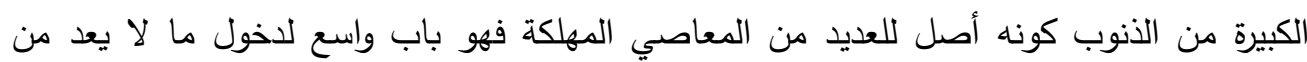
المعاصي اللا محصورة والمهلكات ، فجاء في رواية الكليني بإسناده عن امير المؤمنين " عليه السلام " قال : (( والنفاق على اربع دعائم : على الهوى ، والهوينا ، والحفيظة ، والطمع ، فالهوى على اربع شعب :على البغي ، والعدوان ،والثهوة ، والطغيان فمن بغى كثرت غوائله وتخلى منه وقصر عليه ، ومن اعتدى لم يؤمن بوائقه ولم يسلم قلبه ولم يملك نفسه عن الثهوات ، ومن لم يعدل نفسه في

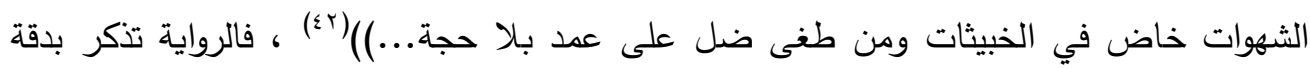
أصول النفاق وفروعه ومدى قبحها وتأثيرها في الابتعاد عن الله ودينه بُعداً كثيرا ، وفساد الدين والدنيا لمن اتصف بتلك الصفات ، ولطول الرواية نقتصر على توضيح بعض الموارد التي تؤكد ذلك ، فتذكر الرواية أن للنفاق أربعة أصول : الهوى والهوينا والحفيظة والطمع ، ولكل اصل من هذه لهن الاصول فروع تتدرج تحتها ملازمة لها تصف بشكل أو بآخر مدى مفسدة النفاق ، ولتشعب الفروع والاصول سأكتفي بالأصل الأول وفروعه مع توضيح معاني ومقاصد الاصول الاربعة حتى يتبين المقصود بها ويتضح المطلوب فلا حاجة لذكرها جميعا تلافياً للإطناب .

فالأصل الأول : الهوى الذي يدل على ميول النفس وارادتها للعمل بمقتضى طباعها(ז\&) ، وهو مختص بالاعتقادات والاداء(๕) ، لذلك كانت أقرب في معناها إلى الخروج عن حدود الله وهو من أشد الأمور ميلا عن الحق وأعظم محرف عن اتباع سبيله واقواها على سلوك طريق النفاق(0) . والأصل الثاني : الهوينا : قيل هي الفتتة الصغرى التي تقود الى الكبرى لان الفتن تترتب

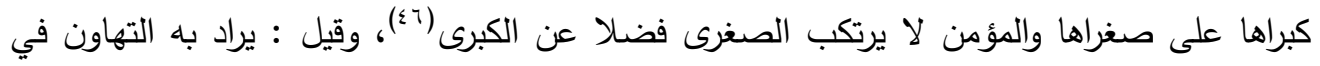


العـــــــد السادس والثلاثون

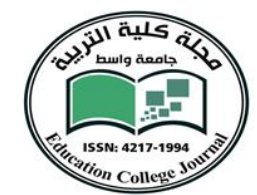

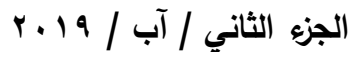

جامعة واسط

مجلــــة كليـــــة التربيــــة

امر الدين وترك الاهتمام به(^) ، والاصل الثالث : الحفيظة : وهي الغضب(^^) ، وهي في الانسان التغير على الغير قصداً للإساءة اليه(9) .

والرابع : الطمع ويعني ((توقع الدنيا وما في أيدي الناس وهما أكثر مصارع النفوس واخص

افعال الشيطان وأضر احوال الناس )(م) (0)

ومن خلال معاني هذه الأصول المكوّنة للنفاق يتوضح جلياً مدى قبح النفاق ، واجتماع تلك

الاوصاف في شخصية المنافق تبين مدى عظمة الفساد المترتب على النفاق .

ولطول الرواية وتشعبها سأكتفي بتوضيح الفروع التي تتدرج تحت الاصل الاول، فقوله "

عليه السلام " : ((والهوى على اربعة شعب : على البغي ، والعدوان ، والشهوة ، والطغيان)) لاشك أن البغي من الافعال القبيحة المذمومة لما فيها من التجاوز والاعتداء وقصد الاستيلاء والتجبر على العباد ويلازمها مفاسد متعددة على مستوى القوى العقلية التي بفسادها يعيش الفرد بضلال ، وعلى مستوى القوى الغضبية والتي بفسادها تفسد مطالبه بمخالفة الحق والتجبر على أهله ،وآخر على مستوى القوى الشهوية التي تفسد واقعه إذ بفسادها يتبع المنافق ما تشتهي نفسه من المعاصي (') ، وهذا ما لا يخفى إذ تجتمع في النفاق مفاسد عديدة غير محصورة تفسد واقعه وتوقعه في دنس شهواته واختلال موازين الامور الصالحة لايه ، ففساد عماد النفس البشرية يعني فسادها عموما وكل ما يصدر منها بعد ذلك فهو فاسد مفسد ، كون الانسان كما هو معلوم هو كيان مترابط من القوى المختلفة من الشهوية والغضبية والعقلية وفساد هذه القوى يؤول لاختلال في نظامه الذي تقوَّم عليه ، وكل إختلال وتغيير · سلبي · عن النظام المرسوم هو فساد .

وأما العدوان فما يتبادر منه كافيا لإنْ يبين مدى قباحته وما يترتب عليه، بما فيه من الظلم الصريح ومجاوزة الشيء لغيره(r) ، ولاشك ان المنافق بنفاقه ومصاحبته لكل من المسلمين والكافرين وانتمائه للكفر ، فذلك يعني انه بمخالطته لهم واظهار لهم الحسنى يكون لله هدف لمصلحته ، أو مصلحة الكفر واهله ، ويتمثل ذلك بالإعتداء على الخلق واخذ الحقوق وغير ذلك وهذا ناتج ايضا عن 
العـــــــد السادس والثلاثون

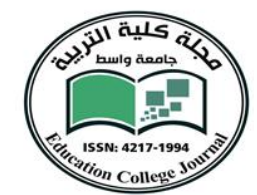

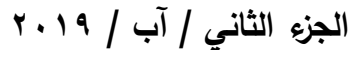

جامعة واسط

مجلــــة كليـــــة التربيــــة

فساد القوى المزبورة في الفرع السابق(ro) ، ومعلوم ان الاعتداء على الآخرين ومجاوزة الحد بالظلم والتجاوز على الآخر من اشد الامور المنهي عنها مما يعني ان فعلها وارتكابها معصية يُعاقب عليها

وما استحق العقوبة فهو فساد أو به فساد .

أما الشهوة والتي تمثل الحب والرغبة في الثيء(\&) ، ومطالبة النفس وتوقانها الى ما فيه

لذة ، وقيل انها تتعلق بما فيه لذة من المدركات(00) ، والظاهر ان غريزة الثهوة وضعت في الانسان لغرض الاختبار وبيان اتزان النفس في السير والافراط بتلبيتها ، لذلك وضعت كمقياس لمعرفة درجة الايمان ، كما يبدو · وهو الظاهر ايضا - ان المنافق لا يتحرج بل هو مفرط في السير مع شهواته

والميل الى المعاصي واغراءات الدنيا ، ومبدأ ذلك فساد القوى الثهوية وتجاوز حد الاعتدال(هo) .

والطغيان الذي يعني : (( مجاوزة القدر في الكفر))(ㅇ) ، أو فيه وفي الشر(ه) ،

والاسراف بالمعاصي والظلم(ه) ،ومجاوزة القدر في كل شيء سواء بالمال أو بالنسب أو العلم وغيره من الامور (•י)، وذلك عين الفساد بلا شك.

فمن اتصف بتلك الاوصاف اجتمعت فيه نتائجها من المهلكات ، واجتمعت فيه الذميمة من الخصال التي تؤول لضرر صاحبها وغيره ، وخاض في المعاصي ولم يملك نفسه عن زجرها وعن العمل بطباعها الداعية الى السوء ؛ كون المنافق يتصف بنفس عارية عن تلك الملكة والهبة الربانية الرادعة والزاجرة عن تلك القبائح (17).

توضيح هذا القدر من افعال المنافق وافساده كافٍ لئن يوضح ويحقق المطلب بإثبات ان النفاق فساد في الأرض بل هو من اشدها وأخطرها على الاسلام والمسلمين، واكثرها ضرراً وهلكة للمنافق نفسه ، وهذا يعم ما ذكره المفسرون من المفاسد على مستوى العقيدة والنظام بشكل عام. 
العـــــــد السادس والثلاثون

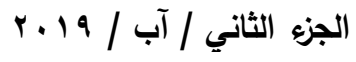

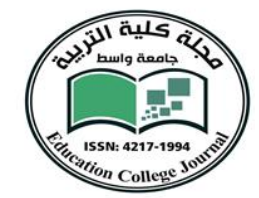

جامعة واسط

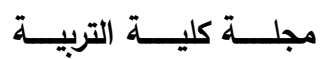

الخاتمة

الحمد الله الذي منّ وأكرم ووفق لإنجاز هذا البحث المتواضع فبعد هذه الرفقة المباركة مع كتاب الله وسنة نبيه الاكرم يروم الباحث ان يدوّن في هذا الموضع اهم النتائج التي توصدل اليها والتي يمكن تلخيصها بالآتي :

ا ـ يتمحور المدلول اللغوي للنفاق حول معنى التستر وإخفاء الثيء واظهار للعلن ما ينافيه ، اما في الاصطلاح فهو ما يدل على اخفاء الكفر واظهار الاسلام • r. وصف القرآن الكريم النفاق بأنه فساد في الأرض ، ووصف المنافقين بالمفسدين في الأرض لما فيهما ويترتب عليهما من الفساد . r. بتخل افساد المنافقين جوانب متعددة منها : افسادهم العقيدة سواء بالكفر أو بإثارة الشبه بقلوب ضعيفي الايمان أو بمحاولتهم اضعاف الاسلام بضربه من الداخل ، ويتجاوز افسادهم لمستوى الناس والنظام العام من خلال اتخاذ اهلهم وعيالهم قدوة سيئة لهم ، واما النظام العام فيفسد نتيجة الآثار المترتبة على افعالهم الفاسدة التي تُفسد اسباب الخير والصلاح • ع. ـ تكرر إلصاق صفة الفساد بالنفاق والمنافقين والنهي عنه وإن دلّ هذا على شيء فإنه يدل على قبح فعل الفساد وفاعله . . . ه. عرضت السنة الثريفة للنفاق اصول وفروع ومجموع هذه الاصول والفروع ومعانيها تتم على ان النفاق ما هو إلا فساد محض . 


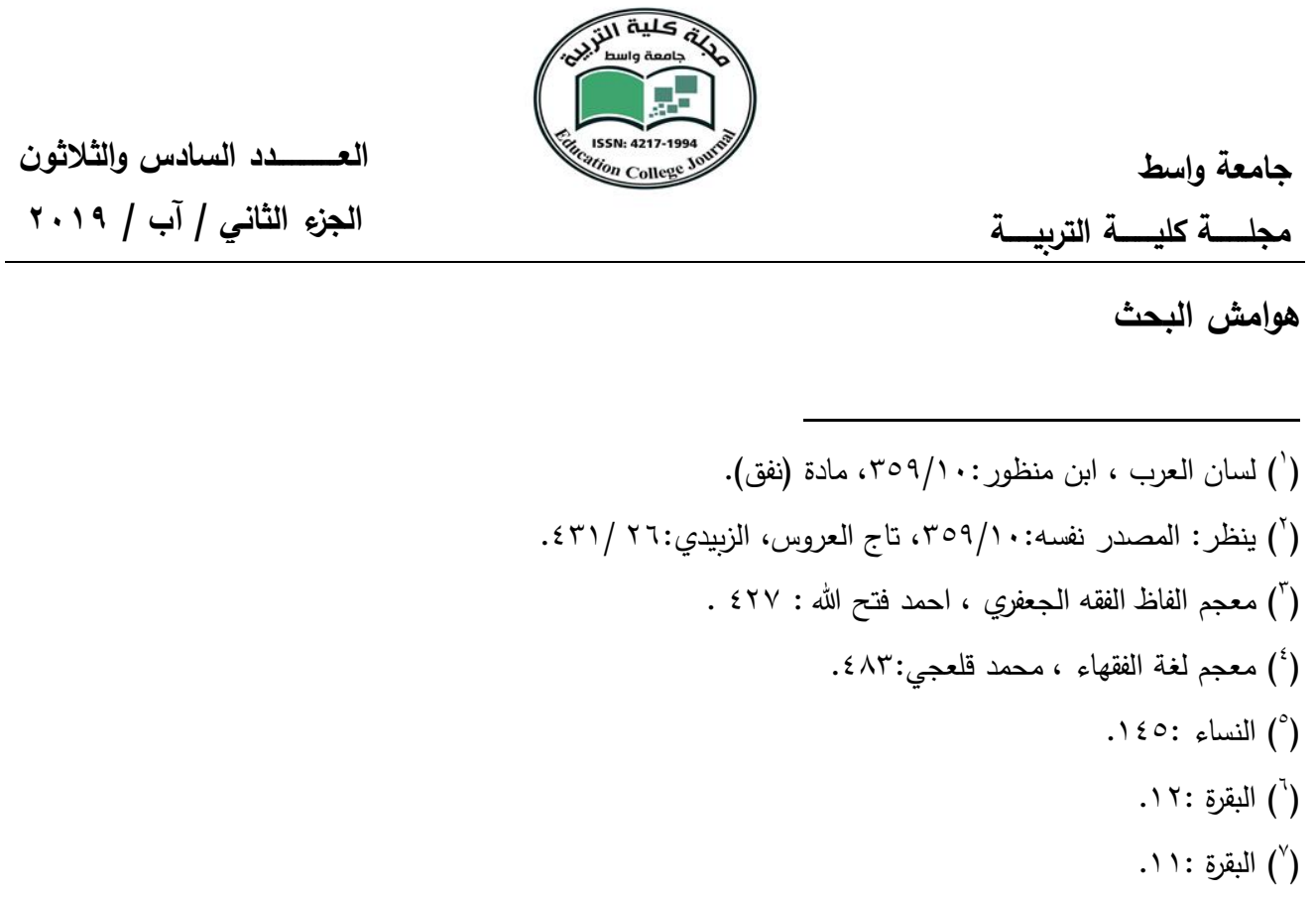

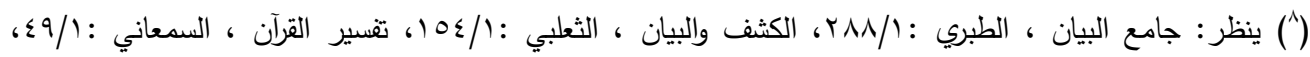

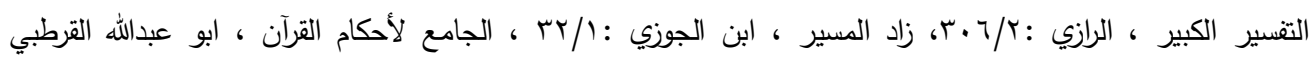

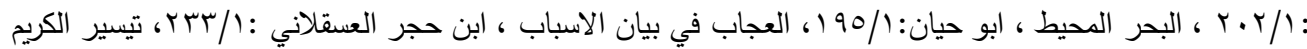

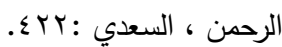

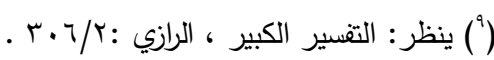

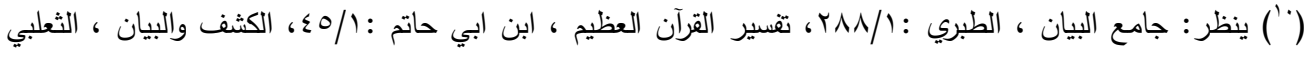

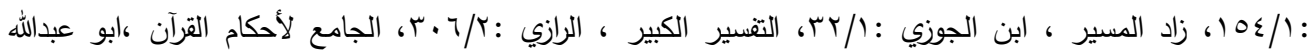

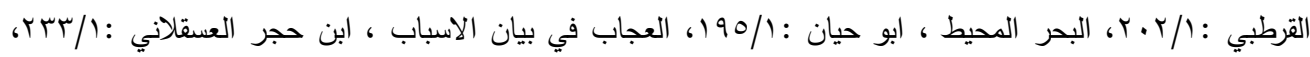
تيسير الكريم الرحمن ، السعدي:r؟ ، من وحي القرآن ، محمد حسين فضل الله : / إع ا.

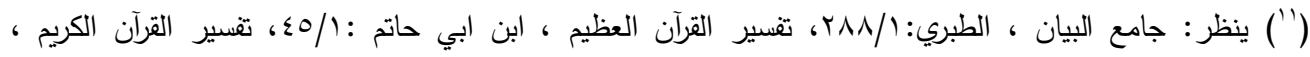
مصطفى الخميني :ro/r.

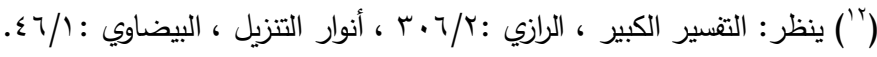

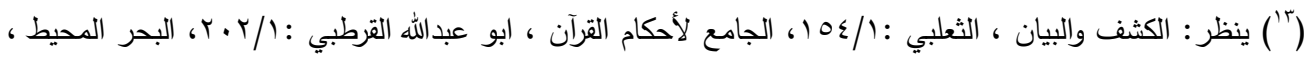

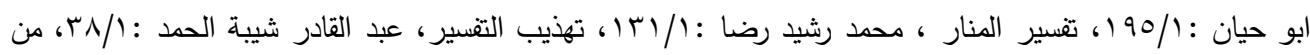

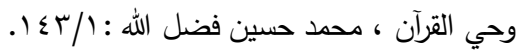

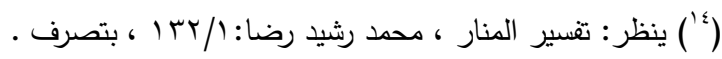

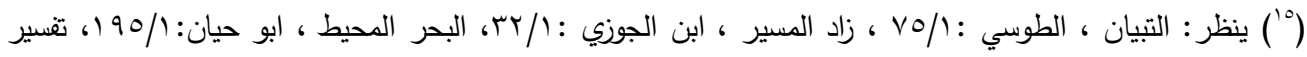

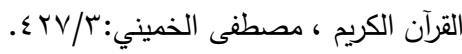


("17) ينظر: الكثف والبيان ، الثعلبي :10/10/ البحر المحيط ، ابو حيان:190/، من وحي القرآن ، محمد حسين

$$
\begin{aligned}
& \text { فضل الله: // 1 1. }
\end{aligned}
$$

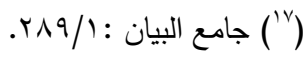

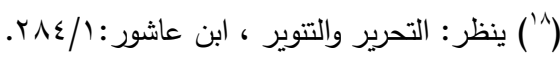

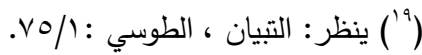

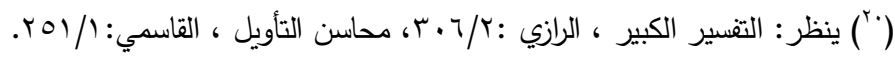

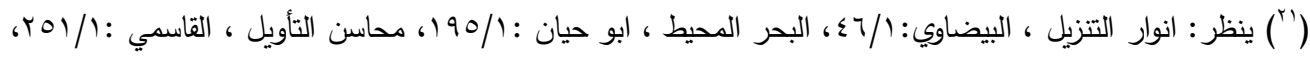

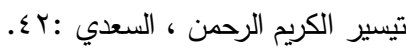

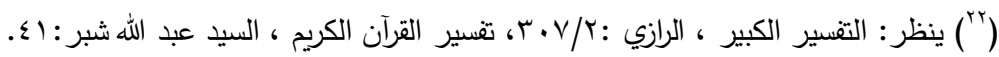

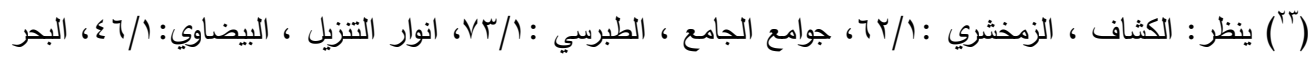

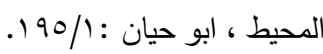
( ) (

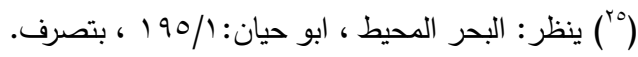
r.0: :

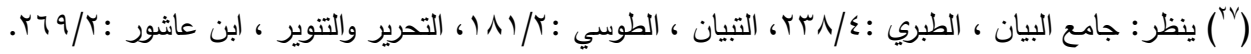

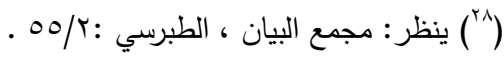

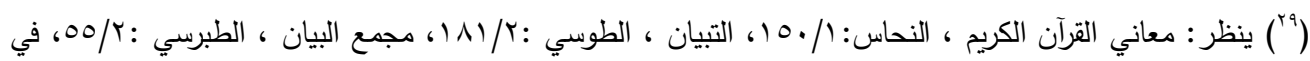

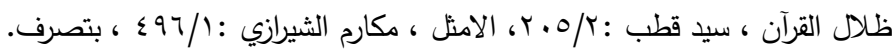
.

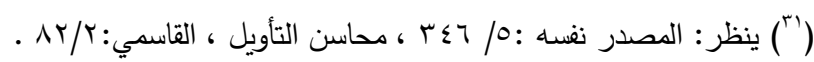

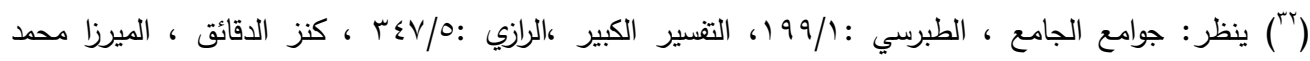

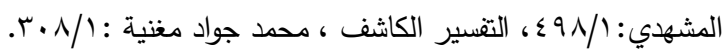

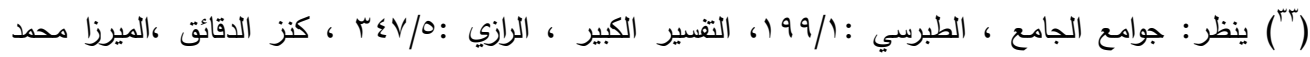

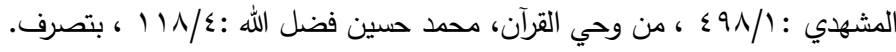

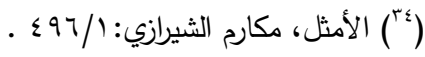
( )

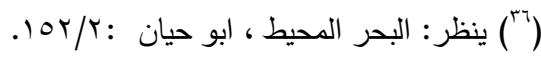




\section{العـــــــد السادس والثثلاثون}

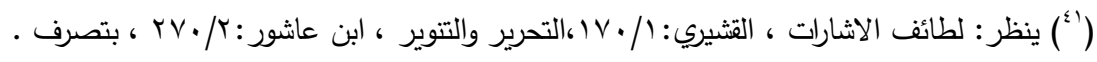

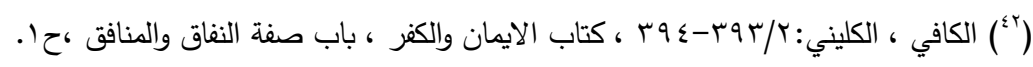

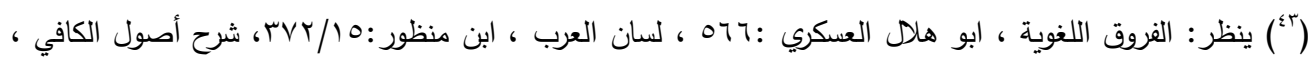

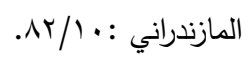

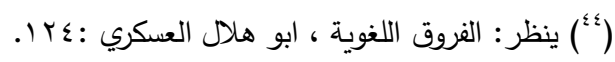

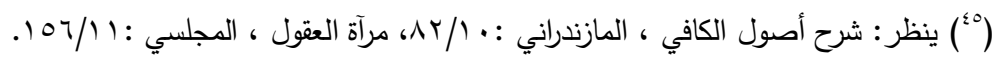

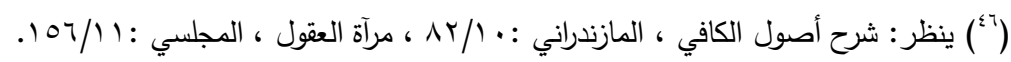
|

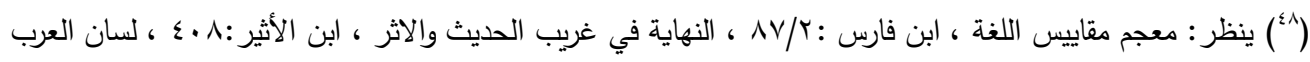

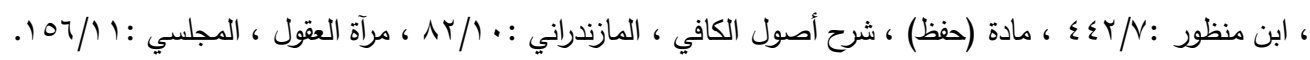

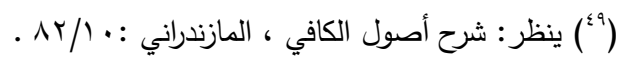

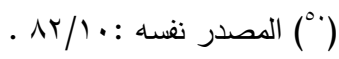

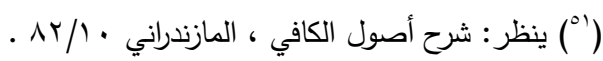

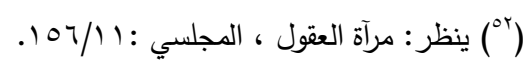

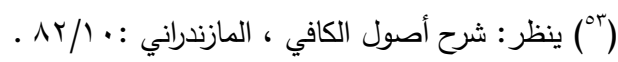

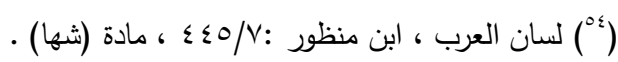

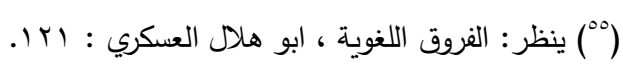

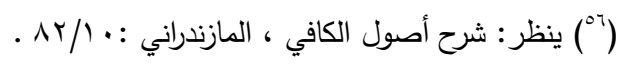

( ) لسان العرب ، ابن منظور : v/10v ، مادة (طغى).

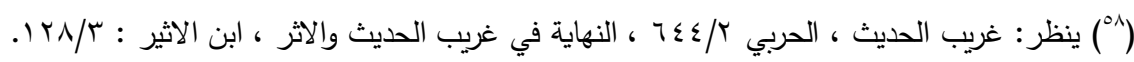

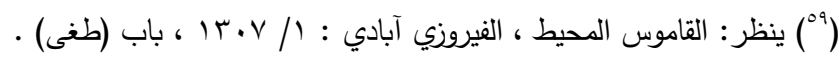

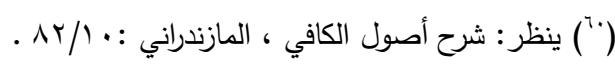

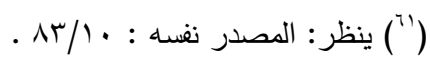




\section{المصادر والمراجع}

• القرآن الكريم

1. الأصول من الكافي ، ثقة الإسلام أبي جعفر محمد بن يعقوب بن إسحاق الكليني الرازي ، ( ت : 9rاهـ ) ،

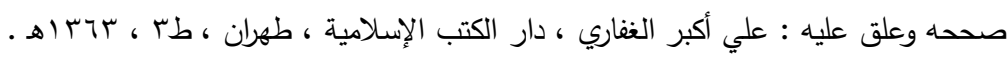

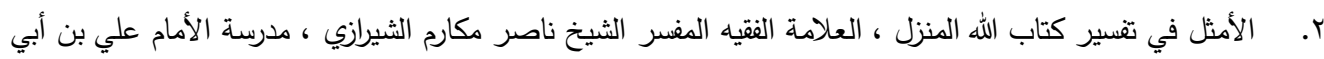

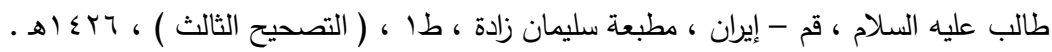

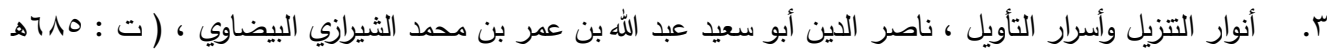

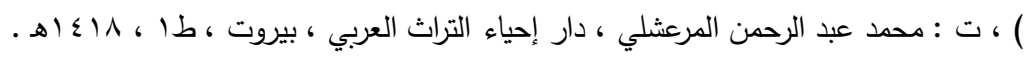
ع. البحر المحيط في التتسير ، أبو حيان محمد بن يوسف بن علي بن يوسف بن حيان أثير الدين الأندلسي ، ( ت :

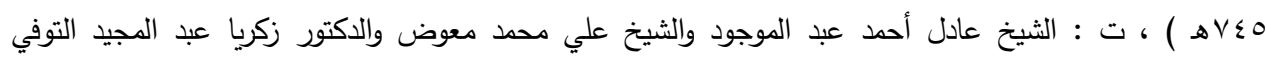

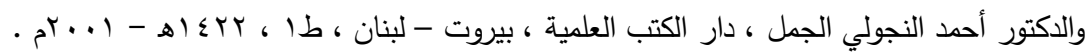

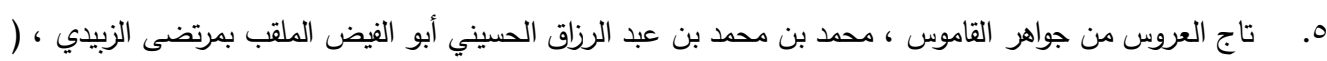

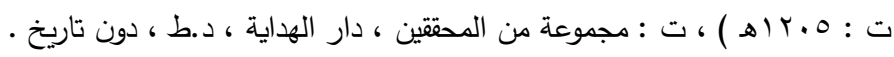

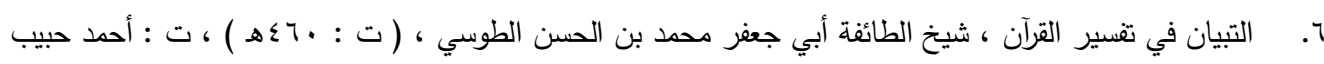

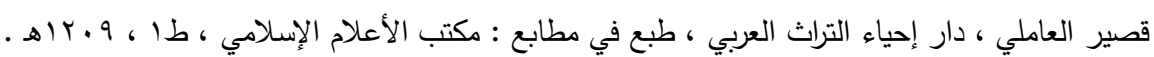

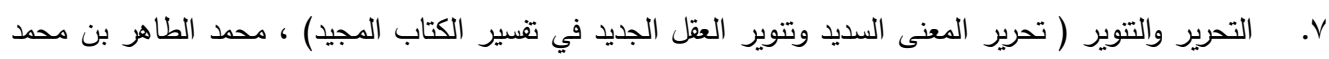

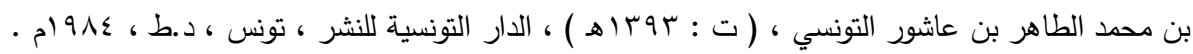

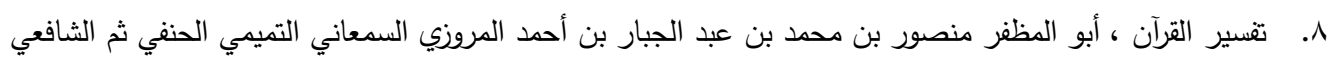
، ( ) :

$$
\text { - م199V-ه } 1 \text { (1) }
$$

9. تقسير القرآن الحكيم ( تفسير المنار ) ، محمد رشيد بن علي رضا بن محمد شمس الدين بن محمد بهاء الدين بن

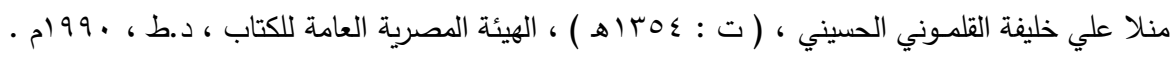
•

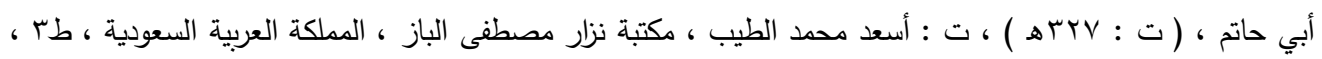


با. تقفير القرآن الكريم مفتاح أحسن الخزائن الإلهية ، العلامة المحقق آية الله المجاهد الثهيد السعيد مصطفى

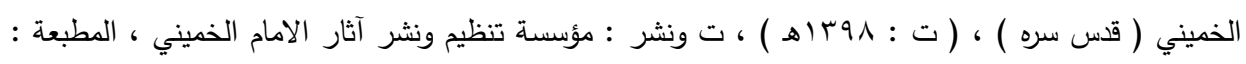

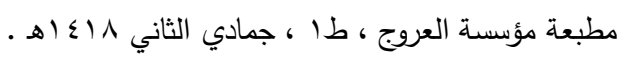
با. التقسير الكاشف ، محمد جواد مغنية ، دار الأنوار للطباعة والنشر والتوزيع ، بيروت - لبنان ، طء ، دون تاريخ ع ا. تفير المراغي ، أحمد بن مصطفى المراغي ، ( ت : الVTاهـ ) ، شركة مكتبة ومطبعة مصطفى البابي الحلبي

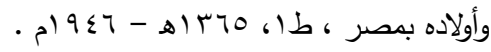
1. . تهذيب التقسير وتجريد التأويل مما أُلحق به من الأباطيل وردئ الأقاويل ، عبد القادر شيية الحمد ، مؤسسة علوم

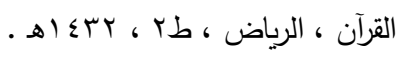

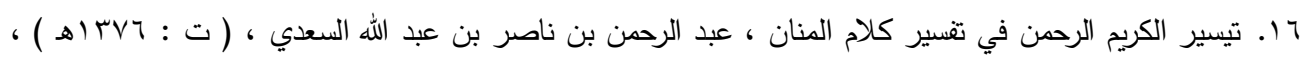

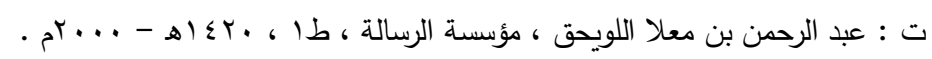

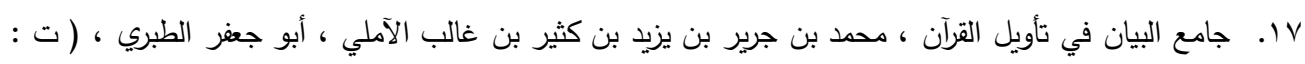

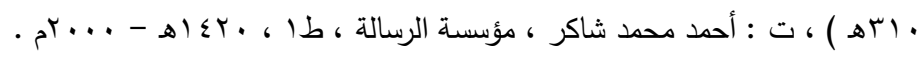

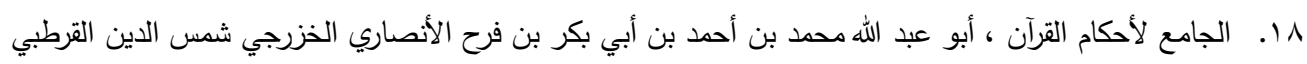

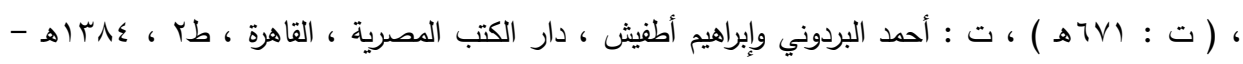
- م) $97 \varepsilon$

9 1. جوامع الجامع ، الثيخ أبي علي الفضل بن الحسن الطبرسي قدس سره ( ت : 1 ــهـ ) ، ت ونشر : مؤسسة

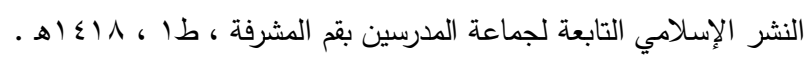

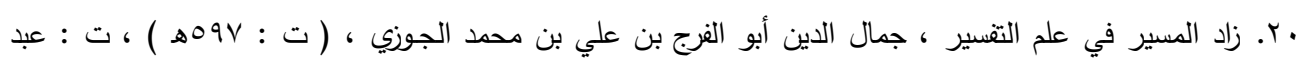

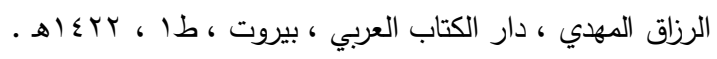

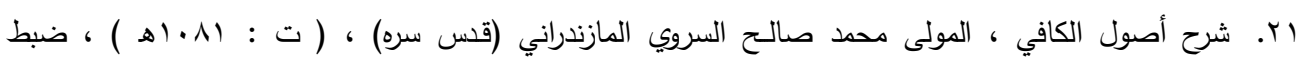

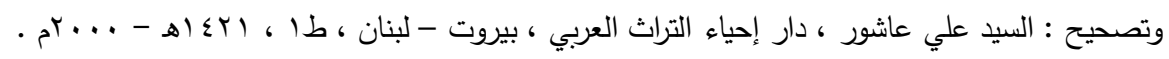

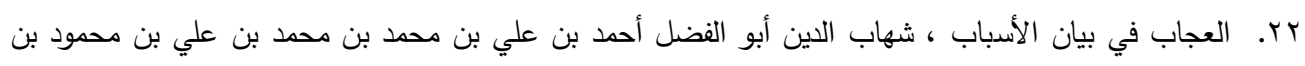

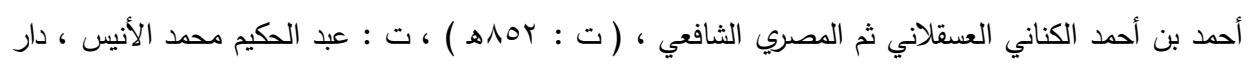

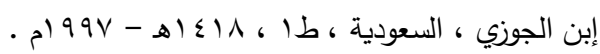

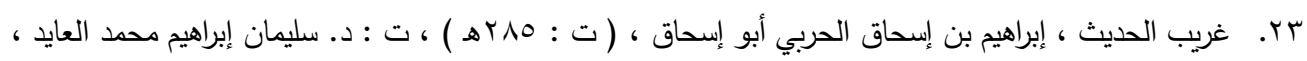

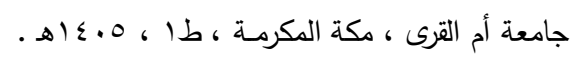


ك r. الفروق اللغوية ، أبو هلال الحسن بن عبد الله بن سهل بن سعيد بن يحيى بن مهران العسكري ، ( ت :

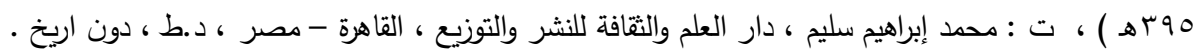

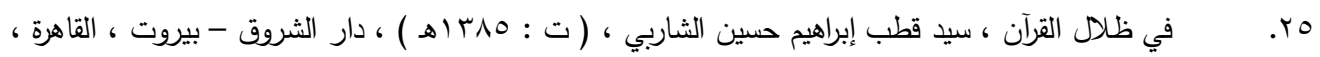
.

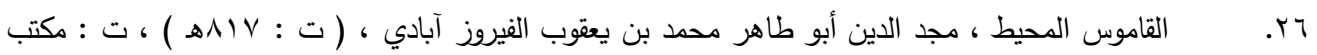

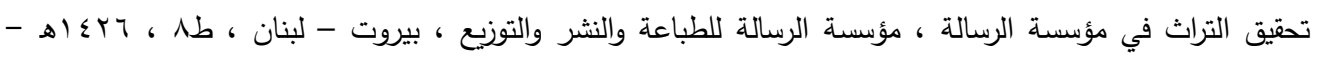
$\cdot 3 r \cdot 0$

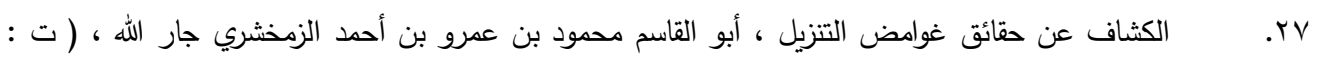

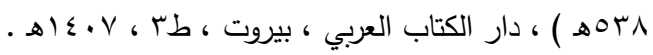

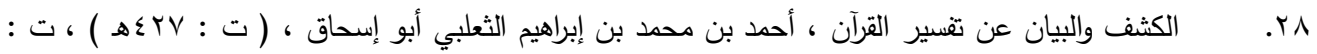

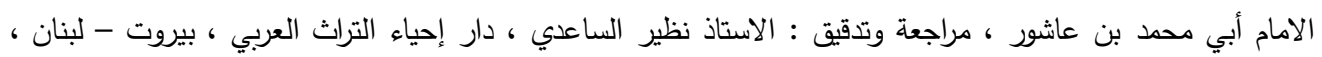

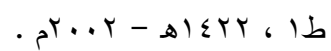
كنز الدقائق ، المفر الكبير والمحقق النحرير العالم العارف الميرزا محمد المشهدي بن محمد رضا بن .49

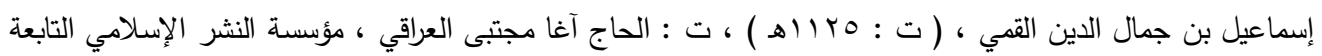

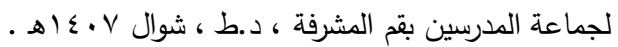

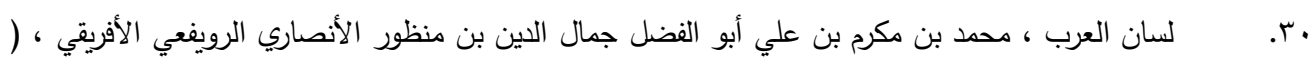

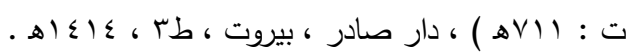

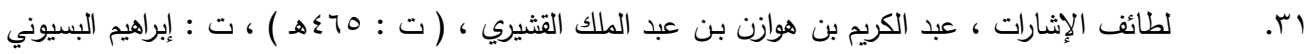

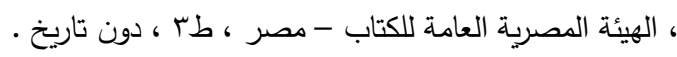

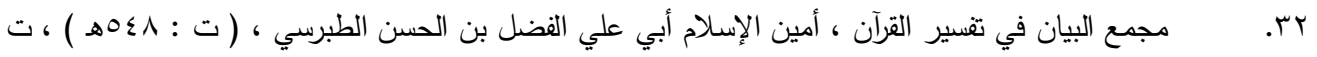

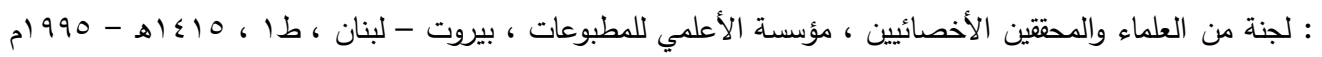

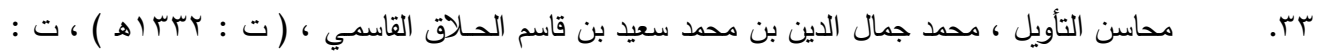

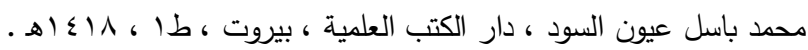

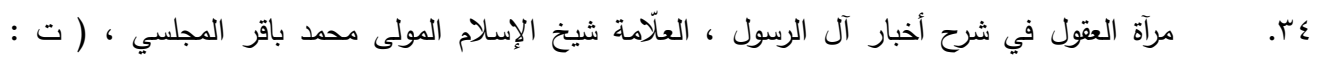

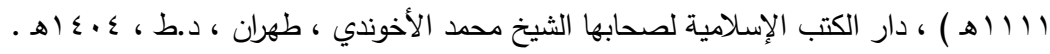


هr. معاني القرآن الكريخ ، الإمام أبي جعفر النحاس ، ( ت : ^بזهـ ) ، ت : الثيخ محمد علي الصابوني ، جامعة

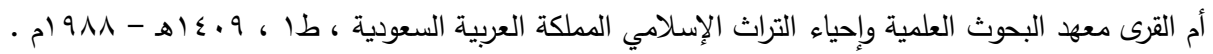

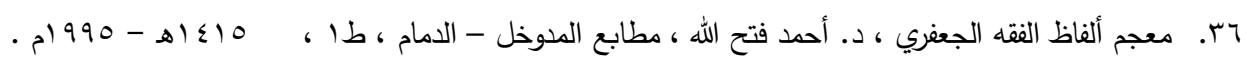

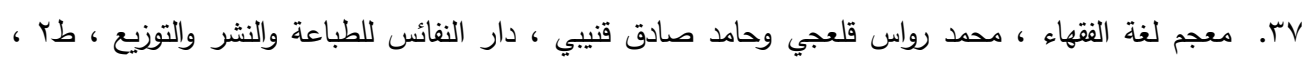

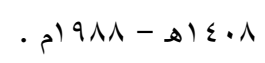

^ז. معجم مقاييس اللغة ، أحمد بن فارس بن زكرياء القزويني الرازي أبو الحسين ، ( ت : 9 هـه ) ، ت : عبد

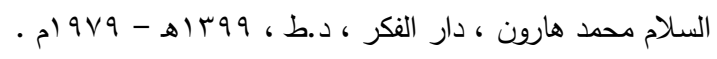

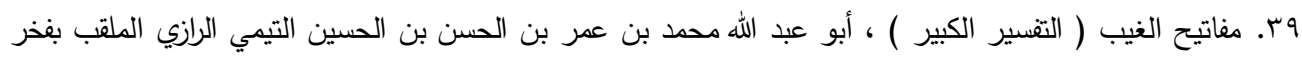

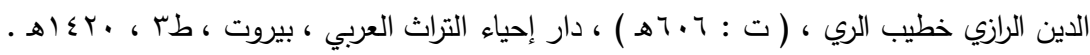

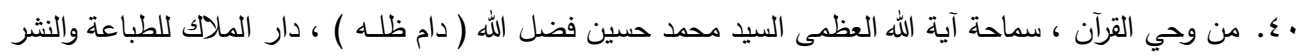

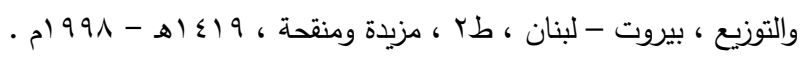

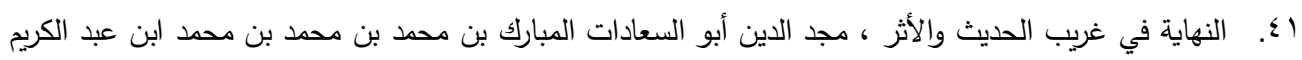

الثيباني الجزري ابن الأثير ، ( ت : ج.7.7ه ) ، ت : طاهر أحمد الزاوي ومحمود محمد الطناحي ، المكتبة

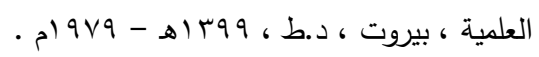

